\title{
AIDS patients family knowledge and behavior toward their patients before and after counseling
}

\author{
Behnam Honarvar \\ From 17th International Symposium on HIV and Emerging Infectious Diseases (ISHEID) \\ Marseille, France. 23-25 May 2012
}

\section{Background}

This study was aimed to measure the effect of ongoing counseling program at behavioral counseling center (BCC) of Shiraz, southern Iran on changing the knowledge, attitude and behavior of AIDS patients' family members toward them.

\section{Methods and materials}

125 members of HIV/AIDS patients' family were interviewed individually by filling questionnaire before and after performing counseling for them. The findings were analyzed in SPSS.

\section{Results}

The age of the participants was $40 \pm 13$ years. Forty four percent had spousal relationships with their patients. Their knowledge about the main routes of HIV transmission were $9.76 \pm 2.59$ and $10.64 \pm 0.88$ before and after counseling, respectively $(\mathrm{P}=0.028)$. Supportive behaviors of families toward their patients reached to $79 \%$ after counseling compared with $44 \%$ before that $(\mathrm{P}=0.004)$. Belief to isolate the patients and the practice of this approach at home dropped from $71 \%$ to $15 \%$ and from $29 \%$ to $7 \%$ after counseling, respectively $(\mathrm{P}<0.05)$. In $30 \%$ of participants fear of getting HIV from patients was not changed by counseling, and $24 \%$ of patients' spouses did report to avoid protected sex with their HIV infected husbands even after taking part in the counseling program $(\mathrm{P}>0.05)$.

\section{Conclusion}

Ongoing counseling for HIV/AIDS patients' families at BCC of Shiraz did advance their knowledge about AIDS and improved their attitude and behavior toward their patients. However, in some aspects such as the removal

Correspondence: honarvarbh32@yahoo.com

Communicable Diseases at Shiraz University of Medical Sciences, Shiraz, Iran of fear about HIVspread in the family or the change of the patients' wives attitude to have protected sex with their HIV infected husbands, the counseling program did not show remarkable success.

Published: 25 May 2012

doi:10.1186/1742-4690-9-S1-P77

Cite this article as: Honarvar: AIDS patients family knowledge and behavior toward their patients before and after counseling. Retrovirology 2012 9(Suppl 1):P77.
Submit your next manuscript to BioMed Central and take full advantage of:

- Convenient online submission

- Thorough peer review

- No space constraints or color figure charges

- Immediate publication on acceptance

- Inclusion in PubMed, CAS, Scopus and Google Scholar

- Research which is freely available for redistribution
C Biomed Central
C Biomed Central

C 2012 Honarvar; licensee BioMed Central Ltd. This is an Open Access article distributed under the terms of the Creative Commons Attribution License (http://creativecommons.org/licenses/by/2.0), which permits unrestricted use, distribution, and reproduction in any medium, provided the original work is properly cited. 